\title{
Pemeriksaan Golongan Darah pada Pelajar Sekolah Islam Terpadu (SIT) Madrasah Tsanawiyah (MTs) Tahfidzul Qur'an Azhar Center Kota Makassar
}

\author{
Rahmawati, Andi Fatmawati, Muawanah, Hasnah \\ Program Studi D3 Teknologi Laboratorium Medis, Politeknik Kesehatan Muhammadiyah Makassar \\ E-mail : rahmawatiamma60@gmail.com
}

\begin{abstract}
The rapid development of technology in this century also affects human health, with the demand for blood for humans increasing. The need for an efficient, fast and precise blood supply is one of the reasons that the blood donated is in accordance with the patient's blood. Therefore, the benefits of blood type examination such as being able to speed up identification for blood transfusion activities, selection of appropriate donors, and analysis of forensic cases. Clinical aspects that can be caused if there is an inappropriate donor selection can cause an immunological transfusion reaction, for example a blood group system that is not compatible with the patient. The implementation of this service is expected to produce outcomes such as the development of knowledge and understanding of the types of blood groups at the school level. The targets for this service are all students in grades 7, 8, 9 at the Integrated Islamic School (SIT) Madrasah Tsanawiyah (MTs) Tahfidzul Qur'an Azhar Center Makassar. The stages of service implementation consist of requesting permission, coordination between the Muhammadiyah Makassar Health Polytechnic and students and preparation of all facilities and infrastructure. The implementation of the activity consisted of checking blood types with a total of 55 students in grades 7, 8, 9 with an age distribution of 11 to 15 years. Based on the blood type examination, the results showed that from 55 participants with details of 21 men and 34 women, the blood types were At, $B+, A B+, O+$ with a total of $15,6,5$ and 29 participants, respectively. Thus it can be concluded that there are $27.27 \%$ of participants with blood type A, 10.9\% blood type B, 9.09\% blood group $A B$, and $52.73 \%$ blood group 0.
\end{abstract}

Keywords: Blood Type, ABO, Rhesus, Madrasah Tsanawiyah

\begin{abstract}
Abstrak
Perkembangan teknologi yang sangat pesat di abad ini, juga berpengaruh terhadap kesehatan manusia, dengan permintaan kebutuhan darah untuk manusia yang meningkat. Kebutuhan persediaan darah yang efisien, cepat dan tepat adalah salah satu alasan agar darah yang didonorkan sesuai dengan darah pasien. Oleh karena itu, adapun manfaat dari pemeriksaan golongan darah seperti dapat mempercepat dalam mengidentifikasi untuk kegiatan transfusi darah, pemilihan pendonor yang sesuai, dan analisis kasus forensik. Aspek klinis yang dapat ditimbulkan jika terjadi pemilihan pendonor yang tidak sesuai dapat menimbulkan reaksi transfusi imunologis misalnya sistem golongan darah yang tidak cocok dengan pasien. Pelaksanaan pengabdian ini diharapkan dapat menghasilkan luaran seperti terjadi pengembangan pengetahuan dan pemahaman tentang jenis-jenis golongan darah di tingkat sekolah. Adapun sasaran pada pengabdian ini adalah seluruh pelajar kelas 7, 8, 9 di Sekolah Islam Terpadu (SIT) Madrasah Tsanawiyah (MTs) Tahfidzul Qur'an Azhar Center Makassar. Tahapan pelaksanaan pengabdian terdiri dari permohonan izin, koordinasi antara pihak Politeknik Kesehatan Muhammadiyah Makassar dengan mahasiswa serta persiapan seluruh sarana dan prasarana. Pelaksanaan kegiatan terdiri dari pemeriksaan
\end{abstract}


Vol.2, No.1 Juni 2021

golongan darah dengan jumlah peserta sebanyak 55 orang pelajar kelas 7, 8, 9 dengan sebaran umur peserta 11 sampai 15 Tahun. Berdasarkan kegiatan pemeriksaan golongan darah menunjukkan hasil bahwa dari 55 peserta dengan rincian 21 orang laki-laki dan 34 orang perempuan diperoleh jenis golongan darah $A+, B+$, $A B+, O+$ dengan jumlah peserta masing-masing 15, 6, 5 dan 29 orang. Dengan demikian dapat disimpulkan bahwa terdapat $27,27 \%$ peserta dengan golongan darah $A, 10,9 \%$ golongan darah $B, 9,09 \%$ golongan darah $A B$, dan $52,73 \%$ golongan darah 0.

Kata Kunci: Golongan Darah, ABO, Rhesus, Madrasah Tsanawiyah

\section{PENDAHULUAN}

Derajat kesehatan masyarakat suatu negara salah satunya dipengaruhi oleh keberadaan sarana kesehatan. Undang-Undang Nomor 36 Tahun 2009 tentang Kesehatan menyatakan bahwa fasilitas pelayanan kesehatan adalah suatu alat dan/atau tempat yang digunakan untuk menyelenggarakan upaya pelayanan kesehatan, baik promotif, preventif, kuratif, maupun rehabilitatif yang dilakukan oleh pemerintah, pemerintah daerah, dan/atau masyarakat (Kemenkes RI, 2015). Adapaun pihak yang terlibat seperti pemerintah, tenaga kesehatan dan masyarakat harus bersinergi dalam menciptakan derajat kesehatan yang baik.

Salah satu upaya yang mudah dilakukan adalah pemeriksaan kesehatan dasar yang bertujuan pencegahan dan penanganan penyakit seperti pemeriksaan golongan darah. Manfaat dari pemeriksaan golongan darah dapat mempercepat dalam mengidentifikasi kasus. Golongan darah penting untuk diketahui dalam hal kepentingan transfusi, donor yang tepat serta identifikasi pada kasus kedokteran forensik seperti identifikasi pada beberapa kasus kriminal (Azmielvita, 2009).

Cairan tubuh berwarna merah merupakan ciri khas darah yang terdapat dalam sistem peredaran darah tertutup yang berfungsi untuk suplay makanan dan oksigen ke seluruh tubuh. Selain itu juga dapat berfungsi untuk pengambilan $\mathrm{CO}_{2}$ dan metabolik dari jaringan tubuh. Pemahaman golongan darah seseorang sangat penting di ketahui untuk kepentingan medis yaitu salah satunya untuk transfusi darah(Fitri, 2007).

Adapun kasus yang memungkinkan tingginya tingkat pendarahan pasien seperti kecelakaan, luka bakar dan proses persalinan yang dapat membutuhkan transfusi darah. Aspek klinis yang dapat ditimbulkan jika terjadi pemilihan pendonor yang tidak sesuai dapat menimbulkan reaksi transfusi imunologis misalnya sistem golongan darah yang tidak cocok dengan pasien. Reaksi transfusi hebat terjadi apabila kasus pemberian darah golongan B kepada penderita golongan A sehingga dapat mengakibatkan kematian karena ketidakcocokan pada sistem golongan darah. Pada transfusi iso agglutinin. misalnya plasma golongan 0 diberikan kepada penderita golongan A dapat menyebabkan reaksi transfusi yang hebat, dan juga dapat menimbulkan kematian (Suminar, 2011).

Secara umum darah memiliki 4 golongan yaitu: golongan darah A dimana golongan darah A mempunyai antigen A dan anti - B, golongan darah B yaitu golongan darah yang memiliki antigen $\mathrm{B}$ dan anti - A, golongan darah 0 golongan darah yang memiliki antibodi tetapi tidak memiliki antigen, dan golongan darah $\mathrm{AB}$ golongan darah yang memiliki antigen tetapi tidak memiliki antibodi (Guyton, 1997). Penentuan jenis golongan darah yang berbeda yaitu A, B, AB, 0 berdasarkan oleh sepasang gen warisan dari kedua orang tua. Antigen merupakan zat kimia yang terletak di permukaan sel darah merah dapat digunakan untuk pengenalan system golongan darah, Pada proses transfusi darah maka golongan darah pasien harus disesuaikan dengan golongan darah pendonor. Kesalahan dalam melakukan transfusi akan dapat menimbulkan komplikasi yang serius (Australia Red Cross, 2008). 
Metode Slide merupakan salah satu metode umum yang dapat digunakan untuk penentuan golongan darah. Prinsip kerja dari metode ini berdasarkan pada reaksi antara aglutinogen (antigen) di permukaan sel darah merah dengan aglutinin yang terdapat dalam serum/plasma yang membentuk aglutinasi atau gumpalan. Metode slide merupakan salah satu metode yang sederhana, cepat dan mudah untuk pemeriksaan golongan darah (Sasmita, 2008).

Berdasarkan penjelasan di atas maka perlu untuk melaksanakan kegiatan pengabdian agar dapat memberikan pengetahuan kepada pelajar SIT MTs TQ Azhar Center Makassar sejak dini tentang jenis-jenis golongan darah.

\section{METODE PENELITIAN}

\section{Alat dan Bahan}

Alat dan bahan yang digunakan dalam pelaksanaan pengabdian kepada masyarakat antara lain kartu golongan, darah darah, alcohol swab, blood lancet, sarung tangan, pen lancet, KIT pemeriksaan golongan darah dan masker.

\section{Tahapan Pelakasanaan Kegiatan}

Proses pelaksanaan kegiatan donor darah telah dilaksanakan sesuai dengan langkahlangkah kegiatan yang telah dirancang sebelumnya yaitu: tim pengabdian menyiapkan, mengumpulkan dan melakukan pendata terhadap siswa yang mengikuti kegiatan pemeriksaan jenis golongan darah dengan menyiapkan kartu uji yang telah disediakan, salah satu ujung jari disterilkan dengan kapas yang telah dibasahi dengan alcohol swab, lancet ditusukkan dengan hatihati ke ujung jari yang telah steril, lalu ujung jari ditekan hingga darah keluar. Darah diteteskan pada kartu uji sebanyak 4 kali pada tempat yang berbeda sesuai dengan nomor dan serum alfa diteteskan sebanyak 1 tetes pada sampel darah pertama, kemudian diaduk menggunakan tusuk gigi dengan gerakan memutar, serta diamati hasil yang terjadi. Selanjutnya langkah untuk ke-3 dilakukan dengan serum yang lain sampai mengetahui golongan darah siswa dan mencatat pada form pemeriksaan serta kartu jenis golongan darah.

\section{HASIL DAN PEMBAHASAN}

Pemeriksaan golongan darah yang dilaksanakan di SIT MTs TQ Azhar Center Makassar dengan peserta seluruh pelajar kelas 7, 89 yang berjumlah 55 orang, jumlah laki-laki dan perempuan berturut-turut 21 dan 34 orang.

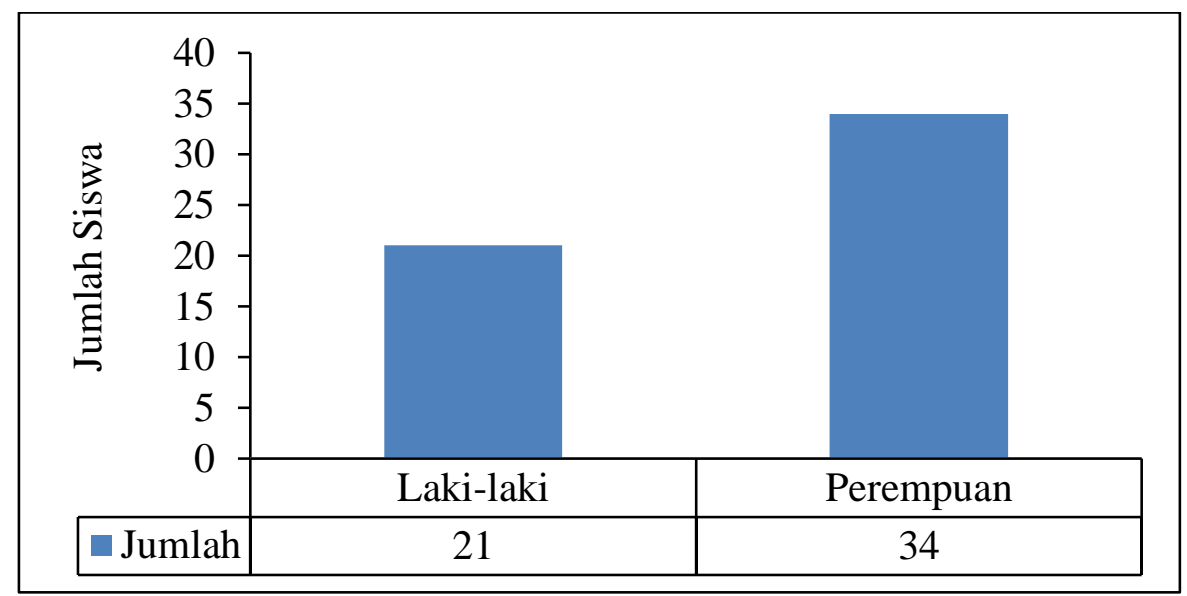

Gambar 1. Jumlah peserta berdasarkan jenis kelamin 
Vol.2, No.1 Juni 2021

Kegiatan awal dari pengabdian dilakukan memberikan pengarahan kepada seluruh peserta terlebih dahulu tentang pentingnya untuk pemeriksaan golongan darah, dan tahapan pelaksanaan pemeriksaan sehingga tidak ada perasaan takut terhadap pelajar. Setiap pelajar akan diberikan blanko pengisian daftar hadir yang berisikan nama, tempat tanggal lahir, dan alamat lalu menuju ke tempat pemeriksaan. Setelah selesai pemeriksaan siswa memperoleh kartu golongan darah.
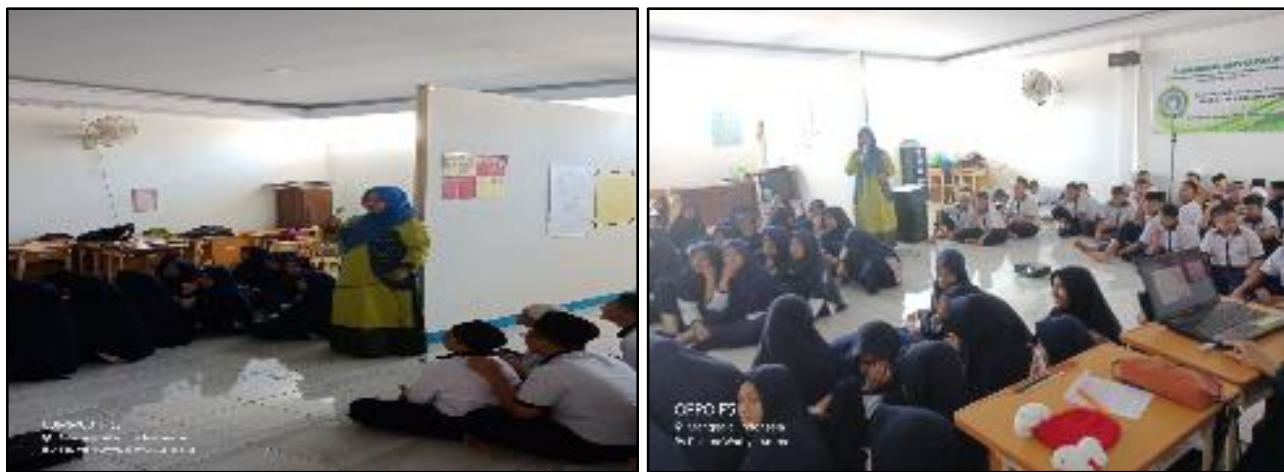

Gambar 2. Pengarahan Kepada Peserta

Pemeriksaan golongan darah dilakukan untuk menentukan jenis golongan darah pada manusia. Metode slide dapat diginakan untuk penentuan jenis golongan darah. Adapaun prinsip kerja dari metode ini didasarkan pada reaksi antara aglutinogen (antigen) pada permukaan eritrosit dengan aglutinin yang terdapat dalam serum atau plasma yang membentuk aglutinasi atau gumpalan.

Golongan darah dapat dideteksi secara sederhana dengan cara meneteskan serum anti-A dan serum anti-B ke darah yang akan dideteksi kemudian melakukan pengamatan langsung terhadap reaksi tetesan serum.


Gambar 3. Pelaksanaan Pemeriksaan Golongan Darah Siswa

Pada hasil pemeriksaan di SIT MTs TQ Azhar Center Makassar, siswa yang bergolongan darah $A, B, A B, O$ masing-masing berjumlah 16, 5, 5 dan 29 orang yang dapat dilihat pada gambar 4. Jenis golongan darah $\mathrm{AB}$ yang diperoleh dengan jumlah paling sedikit diantara jenis golongan darah lainnya. 


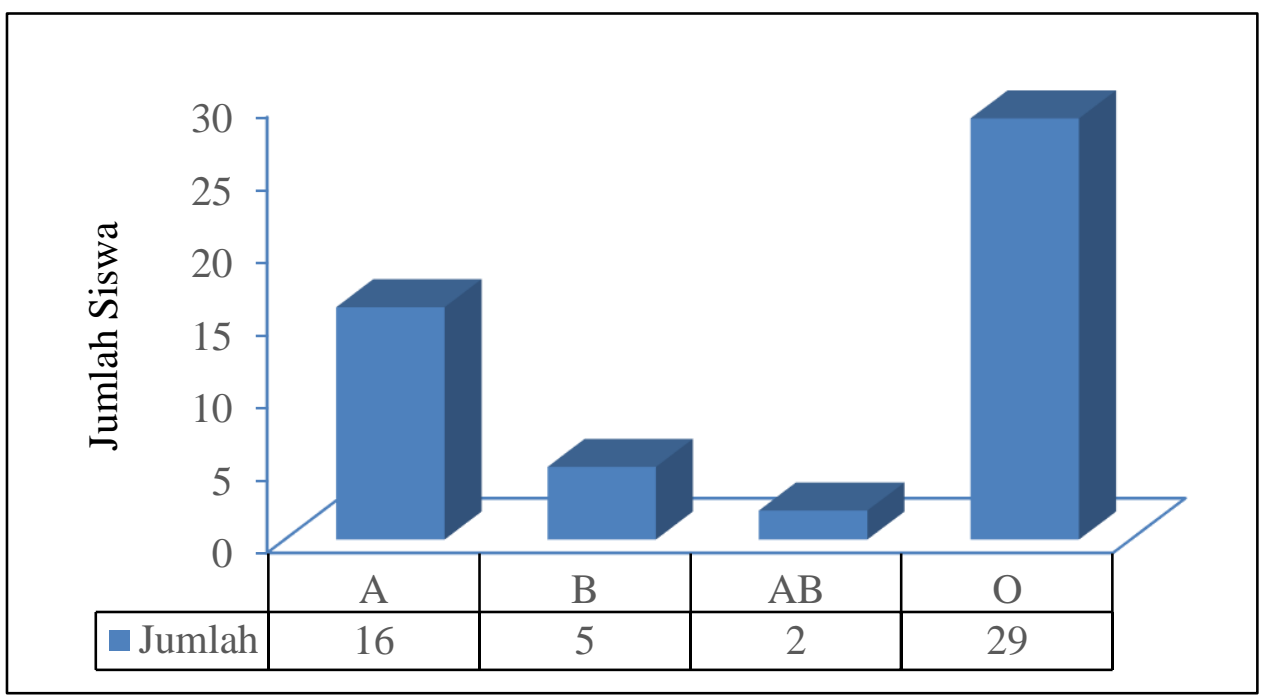

Gambar 4. Jumlah peserta berdasarkan jenis golongan darah

Sebaran persentase yang berbeda dari golongan darah A, B, AB dan 0 ditunjukkan pada hasil pemeriksaan golongan darah untuk setiap pelajar dan secara keseluruhan peserta dapat dilihat pada Gambar 5.



Gambar 5. Persentase Sebaran Data Golongan Darah Peserta

Salah satu ciri khusus darah dari suatu individu yaitu jenis golongan darah karena terdapata perbedaan jenis karbohidrat dan protein pada permukaan membran eritrosit. Golongan darah ditentukan oleh jumlah zat (kemudian disebut antigen) yang terkandung di dalam sel darah merah (Fitri, 2007). Secara umum, golongan darah 0 adalah yang paling umum dijumpai di dunia, meskipun di beberapa negara seperti Swedia dan Norwegia, golongan darah A lebih dominan (Alrasyid, 2010).

Menurut sistem A-B-O bahwa golongan darah merupakan warisan kedua orang tua kepada anak. Menurut Land-Steiner dalam Suryo (1996) bahwa golongan darah manusia dibagi 
dalam empat golongan yaitu $\mathrm{A}, \mathrm{B}, \mathrm{AB}, \mathrm{O}$ berdasarkan oleh jenis antigen yang terdapat dalam sel darah merah.

Penggolongan A-B-O dan Rhesus (faktor Rh) merupakan dua jenis penggolongan darah yang penting. Sekitar 46 jenis antigen selain antigen A-B-O dan Rh yang jarang dijumpai di dunia. Transfusi darah dari golongan yang tidak kompatibel dapat menyebabkan reaksi transfusi imunologis yang berakibat anemia hemolisis, gagal ginjal, syok, dan kematian (Alrasyid, 2010).

\section{KESIMPULAN}

Berdasarkan hasil kegiatan pengabdian kepada masyarakat dapat disimpulkan bahwa jumlah peserta pemeriksaan golongan darah adalah 55 peserta yang terdiri dari 21 pelajar lakilaki dan 34 pelajar perempuan dengan rincian siswa yang bergolongan darah $A, B, A B$, dan 0 berturut-turut adalah 16, 5, 5 dan 29 orang yang memperoleh wawasan terkait pemahaman tentang jenis golongan darah sejak dini.

\section{UCAPAN TERIMAKASIH}

Penulis mengucapkan terima kasih kepada direktur dan Lembaga Penelitian dan Pengabdian kepada Masyarakat (LPPM) Politeknik Kesehatan Muhammadiyah Makassar serta ketua Program Studi D3 Teknologi Laboratorium Medik atas kesempatan melaksanakan pengabdian kepada masyarakat serta bantuan dana dalam penyelenggaraan kegiatan.

Kepala Sekolah SIT MTs TQ Azhar Center Makassar, guru dan staf sekolah, serta siswasiswi kelas 7, 8, dan 9 atas kesediaan meluangkan waktu dan tempat dalam pelaksanaan kegiatan.

\section{DAFTAR PUSTAKA}

Azmielvita dkk. 2009. Genetika Dasar. FK UNRI 7 April 2010. Dibaca pada http://yayanakhyar.wordpress.com

Alrasyid. 2010. Golongan Darah. Dibaca pada http://forum.upi.edu.com

Australia Red Cross. 2008. Blood Groups, 8 April 2010. Dibaca pada http://www.Bloodservice.com

Fitri. 2007. Manfaat Mengetahui Golongan Darah. 8 April 2010. [Online] http://www.wikimu.com (Diakses 20 April 2018).

Guyton, Arthur C., 1997. Buku Ajar Fisiologi Kedokteran. Edisi V. EGC. Jakarta

Kementerian Kesehatan Republik Indonesia. 2015. Profil Kesehatan Indonesia Tahun 2015. Tersedia pada http://www.depkes.go.id/resources/download/pusdatin/profil-kesehatanindonesia/profil-kesehatan-Indonesia-2015.pdf. Diakses pada 1 Oktober 2018.

Suminar, S.R. 2011. Analisis Hukum Terhadap Pemberian Transfusi Darah Di Rumah Sakit Berdasarkan Undang-Undang No. 44 Tahun 2009 Tentang Rumah Sakit. Jurnal FH.UNISBA. XIII(3).

Sasmita. 2008. Pengenalan Golongan Darah. FT UI. Jakarta. 